\title{
Food Marketing to Children in the Context of a Marketing Maelstrom
}

\author{
SUSAN E. LINN
}

\begin{abstract}
HILDHOOD obesity is a major public health prob$\bigcirc$ lem in the United States, yet US children are targeted as never before with marketing for foods high in sugar, 6 fat, salt, and calories (I). The advertising industry's $\int$ stance is that parents should bear sole responsibility for what and how much their children eat-a simplistic view. We take a close look at the nature, depth, and breadth of food marketing aimed at children.
\end{abstract}

MARKETING MAELSTROM:

THE ESCALATION OF MARKETING TO CHILDREN

While food comprises a large portion of what is marketed to children, food marketing occurs in the context of a myriad of other marketing messages to them as well, including advertising for toys, clothing, accessories, movies, television programs, video games, and countless other consumer goods. Even products traditionally purchased by adults such as automobiles, dog food, and air travel are now being marketed to children. While children have been targets for advertising since the advent of mass marketing, the intensity and frequency of children's current exposure to commercial messages is unprecedented.

Today, children between the ages of 2 and I 8 spend almost forty hours a week outside of school engaged with media, defined in this article as including television, films, video and computer games, radio, and print materials, most of which is commercially driven (2). In spite of the growing popularity of the Internet and computer games, television is still the primary electronic medium with which children engage $(3)$. Children are often alone when they watch television, meaning that no adult is present to help them process the marketing messages permeating the medium. Thirty-two percent of children 
ages two to seven have televisions in their rooms, as do $65 \%$ of children eight to eighteen (4) and $26 \%$ of children under two (5).

While television is the most prevalent medium in children's lives, their access to the Internet-where the lines between content and marketing can be blurred-is growing (6). Companies lure children with "advergaming," in which products are incorporated into computer and video games as a means of advertising. Companies keep children's attention focused on specific brands much longer than with a traditional commercial (7). One site, called Candystand (8) consists of games featuring products from the food conglomerate Kraft, such as Lifesavers, Crème Savers and Jello Pudding Bites (9).

Nor is marketing limited to the time children spend outside of school. In 2000, a report from the federal government's General Accounting Office (GAO) called marketing in schools a "growth industry" (IO). Exclusive beverage contracts, corporate-sponsored teaching materials, book covers featuring ads, and corporate-sponsored newscasts are just a few of the ways that marketing infiltrates educational settings. The advertising industry spin is that parents should bear sole responsibility for protecting children from marketing and that parents are to blame for the unhappy consequences of commercialism (I I).

In the I970s, the changing needs of families outstripped the services provided by public institutions. Children's advocates observed the phenomenon of "latchkey kids." Millions of elementary school children were home alone from the time they finished school until a parent returned from work. By the I980s, the phenomenon sparked studies of their school performance, calls for after-school programs, hotlines for kids to call if they were frightened, and books written to help children survive on their own at home. Parents at work worried that their children were going to be prey for all kinds of predators, and instructed them not to answer the door, or to tell people who telephoned that their parents were busy in the next room.

These children did not go unnoticed by the advertising industry, and a new marketing demographic reflected the vulnerability of children alone at home, unsupervised. As Alan Toman, president of The Marketing Department, an advertising agency, explained in the Chicago Tribune in I988, "Latchkey kids are a natural for a lot of consumer products ... We are just beginning to see companies approaching this particular kids' market, taking seriously how many purchases kids control and calculating how much potential they represent" (I 2). 
That same year, the Thomas J. Lipton Company (now owned by Unilever) put out a magazine called Kidsmart, aimed at latchkey kids and their parents. The magazine contained safety tips and fun projects as well as four pages of ads for Lipton packaged foods such as Cup of Soup, Fun Fruit snacks, and fruit drinks ( $\left.\mathrm{I}_{3}\right)$.

For children whose parents felt safer with them at home than roaming the streets, the major housebound activity was watching television. In I988, the New York Times reported that 80 percent of American kids were watching TV after school. According to the Times, "Marketers have been responding. The value of commercial time sold to national advertisers for syndicated children's programs, primarily between 3 P.M. and 5 P.M. on weekdays, grew from nothing in I982 to \$IO7 million last year" (I4).

The eighties also saw marketers flocking to newly created cable television stations. Campbell's, for instance, created a soup music video to sell Chunky Soup on the popular teen-oriented cable station, MTV. In a prescient twist on the refrain of the day, a vice president of research at the children's cable television station Nickelodeon announced, "The latest European research shows that product preferences develop at a much earlier age than anyone had ever thought ... As people begin to understand this, to see how brand loyalty transfers to adulthood, there is almost nothing that won't be advertised as for children" (I 5 ) (italics added).

The sheer volume of child-targeted marketing is stressful for families (I6). As experts on child rearing urge parents to "pick their battles," parents are overwhelmed by commercially created battles to fight. If they are strict about food, should they also be strict about violent toys, media programs, and music? What about precociously sexualized clothing? Computer, video game, and TV time? Materialism?

As most parents struggle to set limits, corporations often undermine parental authority by encouraging children to nag. They inundate children with images that tend to portray adults as incompetent, mean, or absent and that encourage children to engage in behaviors that are troublesome to parents. A 1999 article in Advertising Age begins, "Mothers are known for instructing children not to play with their food. But increasingly marketers are encouraging them to" (I7). Instead of acquiescing to parents' concerns, the marketing industry often sees parental disapproval as a strong selling point with kids. When discussing the strategy for selling Kraft Lunchables, a market- 
ing expert put it this way, "Parents do not fully approve-they would rather their child ate a more traditional lunch-but this adds to the brand's appeal among children because it reinforces their need to feel in control" (I 8).

The amount of money spent on marketing to children doubled during the I 990 s and was estimated at about \$ I 5 billion annually in 2002 (I9). In general, food companies spend enormous sums on marketing. In 2002, McDonalds spent over \$I.3 billion on advertising in the United States alone, making Burger King's \$650 million seem paltry by comparison. PepsiCo spent more than $\$$ I. I billion, outspending Coca Cola by about $\$ 544,000$ (20). Kraft Foods (owned, incidentally, by tobacco giant Phillip Morris-now called Altria Group), maker of Kraft Macaroni and Cheese, Oreos, and Kool-Aid, spent about \$465 million in 200I (2I). The year before, Burger King spent $\$ 80$ million on advertising just to children (22) and Quaker Oats spent \$I 5 million pitching Cap'n Crunch (23). When it comes to food, children are targets for everything from edible checkers to battery-operated lollipops.

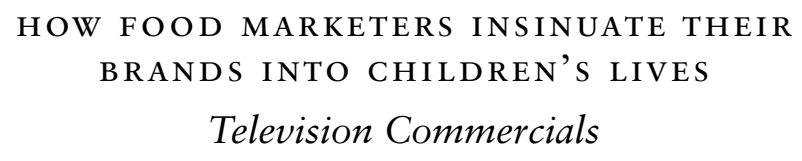

In spite of the growing popularity of the Internet and computer games, television is still the primary medium advertisers use to reach children. Two hours of programming on the Cartoon Network, between 5:30 and 7:30 p.m. on a weekday evening (prime viewing time for children) contained twenty food commercials, or one every six minutes (24). Almost all of the food commercials children see on television are for foods high in calories, fat, salt, and/or sugar (25). Television food advertising is effective. Children's requests for food products, misperceptions about nutrition, and increased caloric intake have been shown to be linked to television advertising. So have parental purchases (26). One 30 second food commercial can affect the brand choices of children as young as two, and repeated exposure has even greater impact (27).

Beyond Commercials:

Tie-ins, Brand Licensing and Product Placement

When considering the degree to which food advertising permeates television viewing for children, we also have to consider brand licensing (when an image or logo is leased for use on products other than the one it was created for) and product placement (when products are 
inserted into the content of programming). Along with most children's movies, many of the TV programs children watch partner with food companies. For instance, in 2003 , six hours of programming on Nickelodeon one Sunday afternoon contained 40 food commercials, or about one every nine minutes. However, that did not include all of the programs whose characters are now icons for food products. Nickelodeon's hit program SpongeBob SquarePants was Kraft's top selling Macaroni and Cheese in 2002 and the number one "face" shaped Good Humor Ice Cream Bar (28). Once a program is associated with a particular brand, the program itself becomes an ad for that food. Visit any supermarket and you'll find shelves filled with examples of these links between media programs and food manufacturers.

Take another Nickelodeon's hit program, Rugrats-Chucky, Angelica, and the other Rugrats tykes now grace packages of Kraft Macaroni and Cheese, as well as Farley's Fruit Rolls, a peanut-butter-and-jelly flavored Good Humor ice cream sandwich, and Amurol bubble gum with comics printed on the gum itself ("view \& chew"). Nickelodeon itself has a line of fruit snacks featuring Nicktoons characters (29).

Tie-ins like these are designed to lure children into selecting foods associated with favorite movie or TV characters. They are also designed to keep children continually reminded of products. As one marketing expert says, corporations are "trying to establish a situation where kids are exposed to their brand in as many different places as possible throughout the course of the day or the week, or almost anywhere they turn in the course of their daily rituals" (30).

Children's introduction to TV-linked calories often begins in earnest with juice. According to Lisa Rant, a beverage industry writer, "The beverage aisle is brimming with brews for babies, and mom can take her pick from a plethora of multi- and single-serve solutions with products packaged specifically for the pediatric set. Apple \& Eve travels down Sesame Street with Elmo's Punch, Big Bird's Apple, Grover's Grape and Bert \& Ernie's Berry juices ... " (3 I).

Sesame Street isn't the only children's program to cash in on juice boxes for the littlest children. Libby's offers juice boxes adorned with Arthur characters, and because "toddlers are naturally drawn to colorful graphics and familiar characters, Mott's made its move with juice boxes that have featured Nickelodeon's Rugrats and, more recently, PBS' Dragon Tales. The innovative Dragon Tales promotion ran for six months, with changes in graphics every 45 days to 'refresh' the campaign" (32). 
From a juice company's point of view-and that of many parentslittle juice boxes or containers make sense: they're small enough for a young child to handle (both physically and with regard to appetite), easy to transport, and relatively unspillable. As Julie Halpin, CEO of The Gepetto Group, explained, "Companies often find it difficult to generate enough volume with a product designed only for infants and toddlers ... Because this is a relatively short life-stage, the product needs to encourage enough purchase frequency to make sense as a business proposition. If the line of products can be broad and appropriate for different times of day and drinking occasions, a brand for this consumer can work" (33). Yet the form of juice packaging the article above extols is exactly the type that the American Academy of Pediatrics has voiced concern over, suggesting that babies and toddlers may be drinking too much juice, citing as a factor its easy portability, in the form of covered cups and juice boxes. In addition to providing babies with too many calories, sipping juice throughout the day may be harmful to young children's teeth $(34)$.

Parents can "just say no" to a toddler's grocery aisle requests. But toddlers, going through the developmental phase of differentiating themselves from their parents, are prone to do so by actively and tenaciously asserting their voice, needs, and wants. For media- or brand-saturated little ones and their parents-even for families who restrict television viewing to public television - a trip to the grocery store may turn into a struggle.

Product placement-when a company pays to have its products inserted in the content of media-is prohibited by law in children's television programming, but is rampant in the prime time programs that are children's favorites. According to Business Week, Coca Cola paid \$20 million for product placement in the TV show American Idol (35) a favorite of teens and pre teens. On The Gilmore Girls, another popular show with children, characters eat Kellogg's Pop Tarts for breakfast (36).

Interestingly enough, the Gilmore Girls was created through a consortium of corporations, including many, such as Kellogg, from the food industry, called The Family Friendly Programming Forum. The stated mission of the Forum is to create programming that is good for families to watch together-programming that is free of excessive violence and explicit sexuality, but not free of marketing food (37).

Thus far, neither films, video games, nor the Internet has regulations about placing brands within the content of their media products aimed at children. For instance, McDonald's food products were 
embedded in the hit children's film Spy Kids. An executive of Heinz, commenting on placing EZ Squirt ketchup in the child-oriented web site NeoPets.com, said that product awareness "just went through the roof ... Trials of the product increased by I 8 per cent" (38). Meanwhile, other fast food outlets, Pizza Hut and KFC, are destinations along the way in the video/arcade game, Crazy Taxi (39).

Product placement can also be found in children's books, including those for babies. Scholastic publishes The M\&M Counting book, and Simon and Schuster has one featuring Oreos. These cardboard books are particularly troublesome because the covers often look exactly like the packaging these foods come in. Literacy experts encourage parents to read to babies and toddlers, citing gains in literacy and the promotion of positive parent-to-baby bonding. Babies and young children whose mothers or fathers read to them-especially when their parents take them on their laps or read to them at bedtime-associate warm, snuggly feelings with reading, and reading itself becomes early on a pleasurable experience for them. However, if the books they are reading include the Hershey Kisses: Counting Board Book or the Skittles Riddles Math book, one can assume that babies are gaining equally warm, snuggly feelings about candy.

Food companies also market to children through toys. Smuckers, for instance, has a Cabbage Patch doll, Peanut Butter and Jelly Kid, designed to sell a product called Goobers. HotWheels makes toy cars sporting the M\&M candy logo. Barbie dolls work at both Pizza Hut and McDonald's, and the latter partners with Play Doh and Easy Bake (40).

RESTRICTING ADVERTISING TO CHILDREN

The United States regulates marketing to children less than most other industrial democracies. Sweden and Norway ban marketing to children under twelve (4I). The Province of Quebec, in Canada, bans marketing to children under I3 (42). Greece prohibits ads for toys on television between 7 A.M. and IO P.M. Ads for toy guns and tanks are not allowed at any time. In the Flemish speaking areas of Belgium, no advertising is allowed within five minutes of a children's television program shown on a local station (43). Advertising regulations proposed by the European Union would ban commercials suggesting that children's acceptance by peers is dependent on their use of a product (44). Finland bans advertisements that are delivered by children or by familiar cartoon characters (45). The French parliament government recently banned all vending machines in middle and secondary schools 
(46). New Zealand is considering a ban on junk food marketing to kids (47). And, in 2004, the British Broadcasting Corporation severed marketing connections between their children's programming and junk food companies $(48)$.

Given their particular vulnerabilities to marketing there is a powerful argument to be made that it is in the best interest of children that companies refrain from marketing to them at all. How can this discussion proceed in the face of the current political climate in the United States that favors deregulation of corporate practices in general? Perhaps the mounting evidence linking food advertising to children's food consumption suggests that the food industry's child targeted marketing is a good place to begin. Even the advertising industry is expecting new regulations. An online poll published in Advertising Age found that $77 \%$ of respondents think that there is a direct link between TV ads and childhood obesity (49). In a poll of professionals involved with marketing to youth, $68 \%$ of the people responding agreed with the statement, "I expect there will be increased regulation of the food and restaurant industry" (50). Therefore, any conversation about curbing childhood obesity should include a hard look at food marketing, culminating in a decision about how, and whether, those who market foods should be allowed to continue their practice of targeting children.

\section{Corrective Actions}

The public health community needs to undertake a massive campaign to educate parents, in particular new parents, about the links between commercial culture and childhood obesity. However, public education in itself is not adequate. On both state and federal levels the government should take steps to restrict the current onslaught of food marketing that targets children. The reality of drafting and bringing to fruition such legislation is both complex and cumbersome, but that should not prevent a creative and rigorous exploration of a wide range of options for restricting food marketing to children.

- Congress could pass the bill currently introduced in the Senate that would return to the Federal Trade Commission the power to regulate marketing to children.

- Corporate tax deductions for advertising and marketing junk food to children could be eliminated. 
- Congress could also act to discourage links between toy and food companies that lead to food branded toys and toy giveaways by fast food companies such as McDonald's and Burger King.

- Legislation might also discourage product placement of food products in movies, video and computer games, and television programs popular with children and adolescents by requiring that such embedded advertising be identified when it occurs.

- Food companies might be prohibited from using advertising techniques that exploit children's developmental vulnerabilities such as commercials that encourage kids to turn to food for empowerment, or to be popular, or for fun. The use of cartoon characters-so appealing to young children-to market food products might be also eliminated.

- State or federal law might prohibit food companies from promotions such as child-targeted sweepstakes and contests, to which young people are particularly susceptible.

- Schools could certainly be discouraged from engaging in sale and marketing of unhealthy food products.

\section{CONCLUSION}

Food marketing is pervasive in children's lives and occurs in the context of a virtual bombardment of commercial messages at home, at school, and in the community. Given the intensity and pervasiveness of marketing to children, it is either cynical or naïve to assume that individual parents should bear the sole burden of shielding children from the potentially harmful effects of a I $5_{5}$ billion industry. Given growing alarm about childhood obesity, among other market related health concerns, we need to look at marketing to children as a societal issue, not just a familial one, and search for solutions that will alter the commercial culture surrounding children and families.

\section{REFERENCES}

I. Dalmeny K, Hanna E, Lobstein T. Broadcasting Bad Health: Why Food Marketing to Children Needs to be Controlled. London: International Association of Food Consumer Food Organizations; 2003. Sponsored by the World Health Organization Consultation on a Global Strategy for Diet and Health. 
2. Roberts DF, Foehr UG, Rideout VJ, Brodie M. Kids \& Media @ the New Millennium. Menlo Park, CA: The Henry J. Kaiser Family Foundation; I999.

3. Ibid.

4. Ibid.

5. Rideout VJ, Vandewater E, Wartella E. Zero to Six: Electronic Media in the Lives of Infants, Toddlers and Preschoolers. Menlo Park: CA: The Henry F. Kaiser Family Foundation; 2003. p. 5.

6. Roberts DF, Foehr UG, Rideout VJ, Brodie M. Kids \& Media @ the New Millennium. Menlo Park, CA: The Henry J. Kaiser Family Foundation; I999.

7. Powell C. Get in the Game. Marketing Magazine. 2003 July 28; IO8(27): II.

8. Candystand.com [homepage on the Internet]. New York: KF Holdings, Inc.; c2004 [cited 2004 March 29]. Available from http://www.candy stand.com.

9. Ibid.

Io. General Accounting Office. Public Education: Commercial Activities in Schools: Report to Congressional Requesters. Washington, D.C.: United States General Accounting Office; 2000. p. 26.

I I. Linn, S. Consuming Kids: The Hostile Takeover of Childhood. New York: The New Press; 2004.

I 2. Latchkey Kid is King in Marketing Realm: Clout Carries over to Buying by Parents. The Chicago Tribune. 1988 July 3 I;Sect. C3.

I3. Dougherty PH. Rodale Press Prepares a Magazine for Lipton. The New York Times. I988 May 9;Sect. D:I I.

I4. Rothenberg R. The Media Business: Ad Scene; For Children Home Alone, A Word From the Sponsor. The New York Times. 1988 May 9;Sect D:8.

I 5. Marshall Cohen, senior vice president for research at Nickelodeon, quoted in: Latchkey Kid is King in Marketing Realm Clout Carries over to Buying by Parents. Chicago Tribune. I988 July 3 I:Sect. C:3.

16. Linn, S. Consuming Kids: The Hostile Takeover of Childhood. New York: The New Press; 2004.

I7. Pollack J. Foods Targeting Children Aren't Just Child's Play: Shape-Shifting Foods, 'Interactive' Products Chase Young Consumers. Advertising Age. I999 March I.

I 8. Neville L. Kids' Brand Must Exercise Pest Control. Brand Strategy. 200 I November 2: I7.

19. Barboza, D. If You Pitch It, They Will Eat. The New York Times, 2003 August 3; Sect. 3:I (col. 2).

20. I00 Leading National Advertisers. Advertising Age. 2003 June 23; $74(25): 2$. 
2I. Voight J. Don't Look Back: Major Advertisers are Driving a Recovery in Media. TV's the First to Benefit. Adweek, Boston Edition 2002 September 30; 43(39).

22. Cebryznski G, Zuber A. Burger Behemoths Shake Up Menu Mix, Marketing Tricks. Nation's Restaurant News. 200I February 5: I.

23. Thompson S. Cap'n Goes AWOL as Sales Flatten; Quaker Redirects Cereal Brand's Marketing Budget to Focus on Kids. Advertising Age, I999 November 22: 8.

24. Ibid.

25. Kotz K, Story M. Food Advertisements During Children's Saturday Morning Television Programming: Are They Consistent with Dietary Recommendations? J Am Dietetic Assn, I 994;94: I 296-I 300.

26. Horgen KB, Choate M, Brownell KD. Television Food Advertising: Targeting Children in a Toxic Environment. In: Singer D, Singer J, editors. Handbook of Children and the Media. Thousand Oaks, CA: Sage; 200I. p. $447-46 \mathrm{I}$.

27. Borzekowski DLG, Robinson TN. The 30-Second Effect: An Experiment Revealing the Impact of Television Commercials on Food Preferences of Preschoolers. J Am Dietetic Assn. 200I;IOI(I): 42-46.

28. Nevius CW. One Extremely Absorbing Cartoon: Nickelodeon's Nutty 'SpongeBob SquarePants' is a Surprise Runaway Success. San Francisco Chronicle. 2003 March 9: 37.

29. "Favorite Brands Teams With Nickelodeon. Professional Candy Buyer." I 999;7(2): 5 I.

30. Bob Brown. MarketResearch.com, quoted in: Kjos T. Marketers Compete Fiercely for Spending on Kids. Knight Ridder Tribune Business News. 2002 April I 5: I.

3I. Rant L. Baby Bottles. Beverage Aisle. 200I;IO(9): 68.

32. Ibid.

33. Julie Halpin, Gepetto Group, quoted in: Rant L. Baby Bottles. Beverage Aisle. 200I;IO(9): 68.

34. American Academy of Pediatrics. The Use and Misuse of Fruit Juice in Pediatrics (REO047). 200I;IO7(5): I2IO-I2I3.

35. Foust D, Grow B. Coke: Wooing the TiVo Generation. Business Week. 2004 March I: 77

36. Reyes S. Into the Mouths of Babes. Brandweek. 2002 May 26.

37. Linn, S. Consuming Kids: The Hostile Takeover of Childhood. New York: The New Press; 2004.

38. Winding E. A Website that Offers Virtual Pets has Found a Successful Way of Advertising to Children. Financial Times. 2002 June IO: I7.

39. Emory G. Brand Names Popping up in Games are Free Advertising-For a Reason: 'You don't pick up a Facial Tissue, you pick up a Kleenex,' Marketer Says. Vancouver Sun. 2002 January 3 I;Sect. F:2. 
4o. Linn, S. What's Up with Food Marketing to Kids. PHAI Obesity Conference 2003: Proceedings of the First Annual Conference on Legal Approaches to the Obesity Epidemic; 2003 June 7; Boston; PHAI; 2003.

4I. Briggs B. Wallace Hints at Ban on Junk Food Adverts as the Best Way to Fight Obesity Among Young. The Herald. 2003 February I:Sect A:I.

42. Rivard N, LeBlanc P. Advertising to Kids in Quebec No Picnic. Strategy. 2000 May 8;Sect. B:Io.

43. Rowan D. Hard Sell, Soft Targets. The London Times. 2002 October I 8;Sect. 2:6.

44. Metherwell M. EU Commission Targets Unfair Businesses Practices. The Sydney Morning Herald. 2003 June I9; 3.

45. Hawkes C. Marketing Food to Children: The Global Regulatory Environment. Geneva: World Health Organization. 2003.

46. Taylor, P. Liberty, equality, fraternity ... obesity? The Globe and Mail. 6 August, 2004; Ar I.

47. Metherwell M. Doctors Urged to Look at TV's Role in Obesity. The Sydney Morning Herald. 2002 December 9; 3.

48. BBC to Limit Ties to Junk Food. The Wall Street Journal. 2004 April 6;Sect. D:5.

49. Advertising Age. 2004 March 8: I8.

50. Harris Interactive/Kid Power poll of Youth Marketers. May, 2004. 70.

\section{SUMMARY}

Childhood obesity is a major public health problem in the United States, yet US children are targeted as never before with marketing for foods high in sugar, fat, salt, and calories. Food marketing to children is highly sophisticated, increasingly well-funded, and takes place within the context of a barrage of other kinds of child-targeted marketing. The proliferation and sophistication of electronic media, the escalation of marketing in schools, changing families, and a political climate that favors deregulation have allowed marketers unprecedented access to children, including babies and toddlers. The notion-promulgated by the food industry-that parents can "just say no" to requests for highly marketed snacks and junk food is simplistic at best and cynical at worst. Instead of being viewed as a familial problem, the current marketing maelstrom should be viewed as a societal issue and addressed as such. Restriction of advertising to children is common in industrial democracies other than the United States-and is just one of many corrective actions that could be taken by our governments. 